is frost bitten, contains more potassium cyanide than the normal plant (No. 2). The plants taken from the field in which the poisoning of stock occurred contained the maximum amount. These plants were very much stunted and almost dry from the lack of water. Although they had been up about six weeks none was over ${ }_{5} 5$ inches high.

The amounts of hydrocyanic acid found in cane and Kafir corn are very small and it is difficult to determin, with certainty; that the quantity is sufficient to kill an animal.

A simple calculation will indicate the amount of the poison that may be present in a cow's stomach. Assuming the capacity of the rumen to be 27.5 liters, the weight of the contents would be approximately, let us say, 200 kilos. Of this amount at least 50 kilos would be dry matter, and, on a basis of $0.01 \%$ of hydrocyanic acid being present in the feed, there would be a total of 5 grams in the stomach. This quantity would, very likely, be sufficient to kill a cow. However, no cases are on record of a beef animal eating 200 kilos (nearly $450 \mathrm{lbs}$.) at one feeding. Besides, the rumen is not emptied at any time but remains in a well-fed animal at about the same weight, the undigestible matter being removed gradually. For these reasons it is not probable that there would be so large an amount of the hydrocyanic acid found in the stomach as has been mentioned in the calculation outlined.

STIL, WATER, OKR,ABOMA.

\title{
THE DETERMINATION OF SULFUR AND CHLORINE IN THE RICE PLANT. ${ }^{1}$
}

BY ALICE R. THOMPSON,

Received August 4, 1913.

In so complex an organism as one of the higher plants it is difficult to determin the true funetions of the various elements found in it. Loew ${ }^{2}$ has defined the uses of sulfur and chlorine in the plant.

Sulfur is found in plants in definit chemical organic compounds, such as edestin, which contains $0.884 \% \mathrm{SO}_{3}$, legumin $0.385 \%$, and gliadin of wheat $1.027 \% .^{3}$

Sulfur also occurs as mustard oils in plants; for example, the mustard seed and onion.

Sulfur in mineral form as sulfates occurs usually in smaller quantities in plants. Arendt, Ulricht, E. Schulze, Berthelot and Andre, and Fraps, ${ }^{4}$ have investigated this form in plants and found it to vary in parts of plants

1 Published with the permission of the Secretary of Agriculture.

2 U. S. Dept. of Agr.,- Div. Veg. Physiology and Path., Bull. 18.

3 This Journal, 24, 140-67 (1902).

- Abstract from Fraps (Det. of Sulfates in Plants); Tamman, Ber., 19, 261 (1886); ref. 26th Ann. Rept., 1903, N. Car., p. 67. 
as well as in plants of different families. Sulfates are also formed from organic sulfur in germinating seeds.

Euler ${ }^{1}$ considers that sulfur is held in reserve form in the plant as cystin,

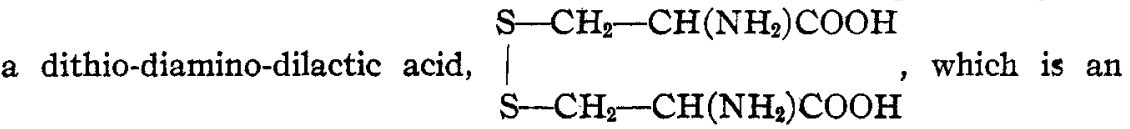
exceedingly energetic compound, from which hydrogen sulfide is split off in small but continuous amounts for the formation of albuminoids.

Chlorine is considered by many investigators to be a superfluous ingredient of plants. As it is present in most soils as the very soluble salts of sodium, potassium and magnesium, the plants may absorb it as they would absorb any soluble salt in the soil. If chlorine be present in considerable amounts it acts as a strong poison. Euler ${ }^{2}$ finds that no organic compound containing chlorine in molecular combination has been isolated from any plant. Nobbe, Siegert, et al., ${ }^{3}$ in their experiments with buckwheat showed that chlorine is required to carry this plant to maturity. Many believe it is necessary for the translocation of carbohydrates in rendering starch soluble. Others (A. Mayer) ${ }^{4}$ hold that even buckwheat can be brought to maturity without chlorine.

In this paper the author has sought to show the sulfur and chlorine content of the parts of the rice plant at three stages of growth, and to determin the effect, if any, of fertilizers on the sulfur and chlorine composition of the plant grown in natural soil conditions and in sand cultures; also, to determin the amounts of sulfur and chlorine contained in the rice field soil and water.

From the obvious increase of sulfate ion in rice plants grown in silica sand and fertilized with ammonium sulfate, one may conclude that ammonium sulfate as such is absorbed by the plant. As shown in a bulletin of this Station, ${ }^{5}$ the rice plant makes its best growth when nitrogen is supplied in the form of ammonia; and on analysis I found free ammonia in the foliage of rice plants grown in the rice fields.

Method of Analysis.-In determining total sulfur in the rice plant, the method used is that of Osborne' $s^{6}$ as modified by Hart and Peterson, ${ }^{7}$ in that the water was not boiled off from the saturated sodium hydroxide solution and the melt was boiled out with water and not with acid.

The author found that not enough emphasis has been placed on the sulfur contamination of gas from the gas burners. In the first analysis

1 Prof. H. Euler, "Pflanzen Chemie," 2 and 3, 146.

2 Loc. cit.

'Landw. Vers. Stat., 4, 7, 13; Prof. Euler, "Pflanzen Chemie," 2 and 3, 149.

4 Jour. Landw., 49, 41-60 (I90I).

- Hawail Agr. Expt. Sta., No. 24.

- This Journal, 24, 142 (1902).

7 Wis. Agr. Expt. Sta., Research Bull. 14, 2. 
of sulfur made, the fusions were made over alcohol lamps but the solutions were boiled in beakers covered with watch glasses, over gas burners. The resulting blank determinations were high in sulfur amounting to $0.03 \%$ of sulfur trioxide. Subsequent determinations were, therefore, made in a room shut off from gas fumes and both fusion and boiling made over alcohol lamps. The resulting blank determinations were practically nil in sulfur, as shown in Table $I$.

\section{Table I,-Blanks on Sodium Peroxide.}

Fused over alcohol lamp but solution boiled over gas flame

Fused and solution boiled over alcohol lamps

Barium sulfate 0.0034 gram

Blank on reagents bromine and nitric acid negligible

In acidifying the alkaline solution of the fused melt I noticed that a good indication of the neutral point is the continuous effervescence due to carbon dioxide or hydrogen peroxide gas that occurs just before the solution becomes acid. Before this stage is reached the effervescence resulting from addition of acid does not continue after each addition of the acid.

The precipitate of barium sulfate was treated with hydrofluoric acid and a few drops of sulfuric acid and ignited a second time to detect traces of silica that in a few cases contaminated the precipitate.

Duplicates on each sulfur determination were made and usually checked within 0.02 and $0.03 \%$.

The mineral sulfur was determined by stirring the sample with $100 \mathrm{cc}$. of $1 \%$ hydrochloric acid solution and allowing it to stand an hour before filtering. (In the case of the starchy grain, the sample was boiled with the solution to render it soluble. No hydrolysis of sulfate occurred by this method, as no trace of sulfate was ever found in the grain.)

Chlorine was determined by the Volhard method (official method). 1

The samples of rice plants for this work were collected March 23, April 19, and May 15, 1912, ten clumps of the plants being selected from each of two plats at the Trial Grounds. The first series of plants was taken before flowering and divided into foliage and roots. The second series was taken at the flowering period and divided into panicles, leaves, stems and roots. The third series was taken at maturity and divided into chaff, grain, leaves, stems and roots.

The plats from which the plants were taken were the unfertilized and the complete ammonium sulfate fertilizer plat.

The following table shows the sulfur and chlorine composition of the rice plant at the first harvest and compares the composition of plants grown in the two plats; one unfertilized, the other fertilized with ammonium sulfate, superphosphate and potassium sulfate.

' v. S. Dept of Agr., Bur. Chem., Bull. 107, 23. 
DETERMINATION OF SULFUR AND CHLORINE IN RICE PLANT. I63I

TAble II-Water-Free Composition at the Furst Harvest. Check plat.

\begin{tabular}{|c|c|c|c|c|c|c|}
\hline & \multicolumn{2}{|c|}{ Gieck piat. } & \multirow[b]{2}{*}{ Total plant. } & \multicolumn{2}{|c|}{ 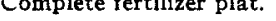 } & \multirow{2}{*}{$\begin{array}{l}\text { Total } \\
\text { plant. }\end{array}$} \\
\hline & Foliage. & Roots. & & Foliage. & Roots. & \\
\hline Total $\mathrm{SO}_{3}$. & 0.489 & 0.492 & 0.491 & 0.393 & 0.430 & 0.401 \\
\hline Mineral $\mathrm{SO}_{3} \ldots$ & 0.057 & 0.208 & 0.107 & 0.079 & 0.188 & 0.102 \\
\hline $\mathrm{Cl} \ldots \ldots \ldots \ldots$ & 0.628 & I .090 & 0.780 & 0.605 & 0.949 & 0.679 \\
\hline
\end{tabular}

In this series the total sulfur percentage is higher than at any other period of growth. It is about equally distributed between the foliage and roots. In the samples from the check plat the total sulfur trioxide is about $0.1 \%$ higher than it is in those from the complete fertilizer plat. This may be due to the fact that the plants in the complete fertilizer plat are much larger and have made more growth.

The percentage of mineral sulfur is highest in the roots, being almost four times as high in the roots as in the foliage. But it is much less than the total sulfur, showing the formation already made of organic sulfur in the plant. Chlorine is also highest at this first period and, like sulfur, is found in largest percentage in the roots.

TABle III.-Water-Free Composition at Second HaRvest.

Check plat.

Complete fertilizer plat.

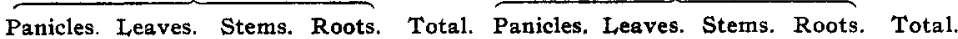

$\begin{array}{lllllllllllllll}\text { Total } \mathrm{SO}_{3} \ldots & 0.245 & 0.395 & 0.169 & 0.305 & 0.2453 & 0.245 & 0.344 & 0.157 & 0.313 & 0.2294\end{array}$

$\begin{array}{lllllllllllll}\text { Mineral } \mathrm{SO}_{3} & 0.000 & 0.056 & 0.009 & 0.143 & 0.0374 & 0.000 & 0.037 & 0.036 & 0.162 & 0.0517\end{array}$

$\begin{array}{lllllllllllll}\mathrm{Cl} \ldots \ldots & \ldots .200 & 0.370 & 0.349 & 0.490 & 0.3534 & 0.174 & 0.345 & 0.35^{2} & 0.446 & 0.3437\end{array}$

At the second period, the difference in composition of the plants grown in the two different plats has become nil and no effect of fertilizers is shown in the percentage composition, although the plants are much larger and heavier in the complete fertilizer plat. The percentage of sulfur in the total plant has decreased from the first period, the leaves having the highest content of sulfur, the stems lowest. No mineral sulfur is found in the panicles, but it is relatively high in the roots and leaves. Chlorine has also decreased in percentage amount and is quite low in the panicles and high in the roots.

TABle IV, - Water-Free Composition at the Third Harvest.

Check plat.

\begin{tabular}{|c|c|c|c|c|}
\hline $\begin{array}{l}\text { Chaff. } \\
\text { Per cent. }\end{array}$ & $\begin{array}{c}\text { Grain. } \\
\text { Per cent. }\end{array}$ & $\begin{array}{l}\text { Leaves. } \\
\text { Per cent. }\end{array}$ & $\begin{array}{l}\text { Stems. } \\
\text { Per cent. }\end{array}$ & $\begin{array}{c}\text { Roots. } \\
\text { Per cent. }\end{array}$ \\
\hline
\end{tabular}

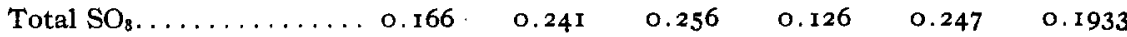

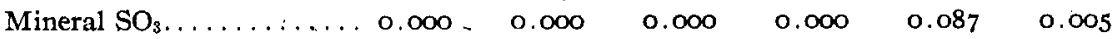

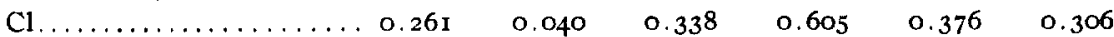

Complete fertilizer plat.

\begin{tabular}{|c|c|c|c|c|}
\hline $\begin{array}{l}\text { Chaff. } \\
\text { Per cent. }\end{array}$ & $\begin{array}{l}\text { Grain. } \\
\text { Per cent. }\end{array}$ & $\begin{array}{l}\text { Leaves. } \\
\text { Per cent. }\end{array}$ & $\begin{array}{l}\text { Stems. } \\
\text { Per cent. }\end{array}$ & $\begin{array}{c}\text { Roots. } \\
\text { Pet cent. }\end{array}$ \\
\hline
\end{tabular}

Total $\mathrm{SO}_{3} \ldots \ldots \ldots \ldots \ldots \ldots$ o. I 8

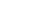

0.231

0.195

O. 120

0.292

0.1763

Mineral $\mathrm{SO}_{3} \ldots \ldots \ldots \ldots \ldots . . . .000$

0.000

0.000

0.000

O. 121

0.008

Cl................ o.246

$0.038 \quad 0.419$

o. 522

0.392

o. 314 
At the third period, the fertilizers show no effect on the composition of the plant. Total sulfur is very small in the stems and chaff and about $0.23 \%$ in the other parts of the plant. Mineral sulfur is found only in the roots, showing that the plant has used up the mineral sulfur in the formation of organic material. Chlorine is practically absent from the grain, though high in the stems.

That considerable amounts of sulfur are removed by various crops from the soil is shown by Hart and Peterson ${ }^{1}$ who suggest need of fertilization of soils by sulfur.

Boullanger ${ }^{2}$ showed the favorable effect of sulfur on the bacterial condition of the soil. Demolon ${ }^{2}$ obtained increased yields by the use of flowers of sulfur as fertilizer and believes it is transformed into sulfates in the soil. Bernhard ${ }^{2}$ also secured larger crops by the use of sulfur fertilizer.

Table V.-Amount per Acre of Sulfur, Phosphoric Acid and Chlorine AbSORBED BX THE RICE PLANT.

\begin{tabular}{|c|c|}
\hline $\begin{array}{l}\text { Check plat. } \\
\text { Founds. }\end{array}$ & $\begin{array}{l}\text { Complete fertilizer plat. } \\
\text { Pounds. }\end{array}$ \\
\hline$\ldots \ldots .9 .5$ & II.9 \\
\hline $\mathrm{Cl} \ldots \ldots \ldots \ldots \ldots 14.9$ & 21.1 \\
\hline $\mathrm{P}_{2} \mathrm{O}_{5} \ldots \ldots \ldots \ldots 28.8$ & 42.0 \\
\hline Calculated as S. . . . 3.8 & 4.8 \\
\hline Calculated as P..... I2.6 & 18.4 \\
\hline
\end{tabular}

The analysis of the soil obtained at the Rice Trial Grounds is shown in Table VI.

Table VI.-ANalysis of the Soll Obtained at the Rice Trial, Grounds. Per cent.

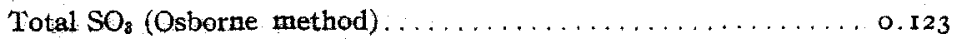

Acid soluble $\mathrm{SO}_{3}$ (official method) $\ldots \ldots \ldots \ldots \ldots \ldots \ldots \ldots, 0.03 \mathrm{r}$

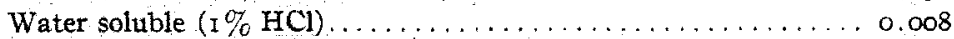

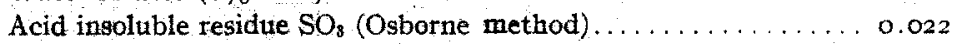

Iron precipitate from official soil solution (Osborne) ......... 0.032

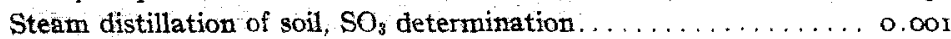

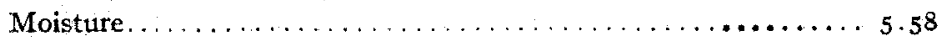

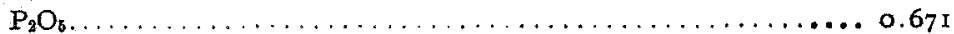

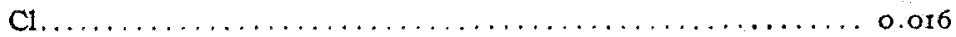

In the Osborne method of determination, the melt solution of soil was filtered in an alkaline condition so that the iron and titanium were separated from the solution in which the sulfate was precipitated. No ammonium salts were thus introduced and ferric chloride was eliminated. ${ }^{3}$ In the official method, however, the iron was precipitated by ammonia in the cold according to Treadwell-Hall ${ }^{4}$ so that no basic iron sulfate would tend to form.

${ }_{1}^{1}$ Wis. Agr. Expt. Sta., Research Bull. $14,5$.

2 International Inst. Agr, Bull. Bur. Agr. Intel. \& Plant. Dis., 3, 1 rog-I I (I9I2).

${ }^{3}$ N. C. Ann. Rept., I902.

" "Analytical Chemistry, Quantitative Analysis," Vol. II, 1909, ist Ed., p. 282. 
The results indicate that the sulfur in the soil is present largely in organic form, since the acid soluble and water soluble sulfur are relatively so small. I could find no trace of sulfide on boiling the soil with hydrochloric acid. Doubtless the presence of large amounts of iron in the soil results in the formation of insoluble basic compounds of sulfur and this may explain the non-effect of sulfur fertilizer on the sulfur composition of rice plants grown in the soil, for, as will be seen later, in silica sand cultures the composition is much affected.

$I$ also subjected the soil to steam distillation and found only $0.00 \mathrm{r} \%$ of sulfur trioxide in the distillate oxidized with bromine.

The soil contains an abundance of phosphoric acid but no large amount of chlorine.

In Table VII is shown the composition of the water entering the rice field and the water standing on the last plat.

\begin{tabular}{|c|c|c|}
\hline & $\begin{array}{l}\text { Artesian watar entering } \\
\text { Rice Trial Grounds. } \\
\text { (Parts per million.) }\end{array}$ & $\begin{array}{l}\text { Water from last } \\
\text { plat in field. } \\
\text { (Parts per million.) }\end{array}$ \\
\hline $\mathrm{CaO}$. & $\ldots \ldots \ldots 6.5$ & 6.6 \\
\hline $\mathrm{MgO}$ & $\ldots .8$ & IO.I \\
\hline $\mathrm{Cl} \ldots$ & $\ldots \ldots 73.8$ & 63.9 \\
\hline $\mathrm{SO}_{3}$. & $\ldots \ldots 8.8$ & 9.0 \\
\hline $\mathrm{NH}_{3}$. & . . . . . none & trace \\
\hline
\end{tabular}

This irrigation water flows over the field and amounts to 25,700 gallons per acre per day and doubtless the plant obtains some of its chlorine and sulfur from the water standing about its roots.

Sulfur trioxide amounts to about nine parts per million and chlorine to seventy parts per million.

Analysis of rain water collected at the Experiment Station showed 3.4 I parts per million of sulfur trioxide. But as the Rice Trial Grounds are situated further from the hills, they received almost no rainfall this year and the soil would receive no sulfur from this source.

Tabla VIII.-Total SUlfur as $\mathrm{SO}_{3}$ IN Moisture-Frefe Material. (Pot Cultures.)

\begin{tabular}{|c|c|c|c|c|c|c|}
\hline \multirow[b]{2}{*}{ Fertilizer. } & \multicolumn{3}{|c|}{ Straw. } & \multicolumn{3}{|c|}{ Paddy. } \\
\hline & $\begin{array}{c}\text { Trial } \\
\text { Grounds } \\
\text { submerged. } \\
\text { Per cent. }\end{array}$ & $\begin{array}{c}\text { Silica } \\
\text { sand } \\
\text { submerged. } \\
\text { Per cent. }\end{array}$ & $\begin{array}{l}\text { Silica } \\
\text { sand not } \\
\text { submerged. } \\
\text { Per cent. }\end{array}$ & $\begin{array}{l}\text { Trial } \\
\text { Grounds } \\
\text { submerged. } \\
\text { Per cent. }\end{array}$ & $\begin{array}{l}\text { Silica } \\
\text { sand } \\
\text { submerged. } \\
\text { Per cent. }\end{array}$ & $\begin{array}{l}\text { Silica } \\
\text { sand not } \\
\text { submerged. } \\
\text { Per cent. }\end{array}$ \\
\hline Check. . . . . . . . . . & 0.215 & $\cdots$ & $\cdots$ & $\cdots$ & $\ldots$ & $\cdots$ \\
\hline$\left(\mathrm{NH}_{4}\right)_{2} \mathrm{SO}_{4} \ldots \ldots \ldots \ldots$ & 0.239 & 0.667 & 0.449 & 0.328 & 0.405 & 0.444 \\
\hline $\mathrm{Mg}\left(\mathrm{NO}_{3}\right)_{2} \ldots \ldots \ldots$ & $\ldots 0.22 \mathrm{I}$ & 0.380 & 0.262 & $\ldots$ & 0.318 & $\cdots$ \\
\hline $\mathrm{NaNO}_{3} \ldots \ldots \ldots \ldots \ldots$ & 0.388 & $\ldots$ & 0.274 & 0.263 & $\cdots$ & $\ldots$ \\
\hline $\mathrm{Ca}\left(\mathrm{NO}_{3}\right)_{2} \ldots \ldots \ldots \ldots$ & 0.267 & 0.343 & $\ldots$ & 0.319 & $\ldots$ & $\ldots$ \\
\hline $\mathrm{NH}_{4} \mathrm{NO}_{3} \ldots \ldots \ldots \ldots$ & . $\quad \ldots$ & 0.508 & 0.310 & $\ldots$ & 0.294 & $\cdots$ \\
\hline$\left(\mathrm{NH}_{4}\right)_{3} \mathrm{PO}_{4} \ldots \ldots \ldots \ldots$ & $\ldots$ & $0.34 \mathrm{I}$ & $\ldots$ & $\ldots$ & 0.302 & $\cdots$ \\
\hline Soy bean cake. . . . . . . & $\ldots$ & $\ldots$ & $\cdots$ & 0.327 & $\ldots$ & $\ldots$ \\
\hline
\end{tabular}


The author took advantage of samples of rice grown in pot culture for nitrogen work as outlined in Bulletin No. 24 of this Station. The plants had received in addition to a basic fertilizer lacking nitrates, as given by MacDougal, ${ }^{1}$ calcium sulfate and the several forms of nitrogen as shown in the table.

In this table no appreciable influence can be seen on the sulfur composition of the plants grown in pots containing Trial Ground soil. But in those plants grown in the silica sand pots, the total sulfur content is higher in every case, and constantly higher when the soluble ammonium sulfate is the fertilizer added. In the following table, the mineral sulfur in the plants is shown:

Tabl. E IX.-Mineral SUlfur in The Plants.

\begin{tabular}{|c|c|c|c|c|c|c|}
\hline \multirow[b]{3}{*}{ Fertilizer. } & \multicolumn{3}{|c|}{ Straw. } & \multicolumn{3}{|c|}{ Paddy. } \\
\hline & $\begin{array}{c}\text { Trial } \\
\text { Grounds } \\
\text { submerged. }\end{array}$ & $\begin{array}{c}\text { Silica } \\
\text { sand } \\
\text { submerged. }\end{array}$ & $\begin{array}{c}\text { Silica } \\
\text { samd not } \\
\text { submerged. }\end{array}$ & $\begin{array}{c}\text { Trial } \\
\text { Grotnds } \\
\text { submerged }\end{array}$ & $\begin{array}{c}\text { Silica } \\
\text { sand } \\
\text { submerged. }\end{array}$ & $\begin{array}{c}\text { Silica } \\
\text { sand not } \\
\text { submerged. }\end{array}$ \\
\hline & Per cent. & Per cent. & Per cent. & Per cent. & Pet cent. & Per cent. \\
\hline Check............ & .0 .052 & $\cdots$ & $\cdots$ & $\cdots$ & $\cdots$ & $\cdots$ \\
\hline$\left(\mathrm{NH}_{4}\right)_{2} \mathrm{SO}_{4}, \ldots \ldots \ldots$ & .0 .106 & 0.435 & 0.148 & none & none & $\ldots$ \\
\hline $\mathbf{M g}\left(\mathrm{NO}_{3}\right)_{2} \ldots \ldots \ldots$ & 0.069 & 0.163 & 0.070 & $\ldots$ & none & $\ldots$ \\
\hline $\mathrm{NaNO}_{3} \ldots \ldots \ldots \ldots$ & 0.098 & $\ldots$ & 0.076 & none & $\cdots$ & . . \\
\hline $\mathrm{Ca}\left(\mathrm{NO}_{3}\right)_{2} \ldots \ldots \ldots$ & $0.06 \mathrm{I}$ & 0.152 & $\ldots$ & none & $\ldots$ & $\ldots$ \\
\hline $\mathrm{NH}_{4} \mathrm{NO}_{3} \ldots \ldots \ldots$ & . $\ldots$ & 0.309 & 0.098 & $\cdots$ & none & $\cdots$ \\
\hline$\left(\mathrm{NH}_{4}\right)_{3} \mathrm{PO}_{4} \ldots \ldots \ldots$ & $\ldots$ & 0.175 & $\cdots$ & $\cdots$ & none & $\cdots$ \\
\hline Soy bean cake. . . . . . & $\ldots$ & $\ldots$ & $\ldots$ & none & $\ldots$ & $\ldots$ \\
\hline
\end{tabular}

These results indicate the increase of total sulfur in the straw to be almost entirely due to mineral sulfur absorbed by the plant.

In Table X, are the analyses of plants grown by the author in silica sand pots to verify the previous results. The chlorine absorbed is about twice as high as that absorbed by the rice plant grown in normal soil conditions. These results with silica sand cultures show that sulfur fertilizer is not rendered insoluble to the plant as is the case in soil cultures. They show the probability of the absorption of ammonium sulfate as such by the rice plant as so much mineral sulfate is found in the foliage, and small amounts of free ammonia were determined in the water solution of two rice plant samples.

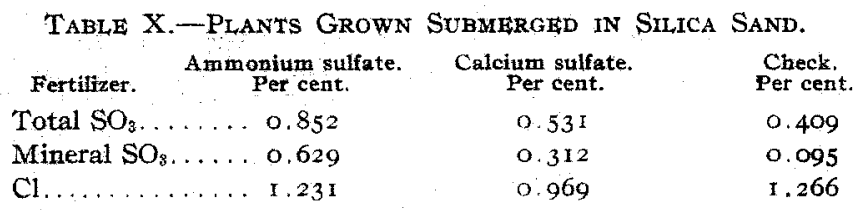

Thanks are due Dr. W. P. Kelley, who suggested this study of the sulfur and chlorine content of the rice plant.

Agr. Expt station, Honolulu, Hawair.

1 "Text-book of Plant Physiology," New York, I9or, p. 225. 